\title{
The Role of Financial Autonomy and Personality in Individual Investment Decisions
}

\author{
Effulgence \\ Vol. 17, No. 1 \\ January - June 2019 \\ Rukmini Devi Institute of Advanced Studies \\ E-mail : effulgence@rdias.ac.in, Website : www.rdias.ac.in \\ http:/ / effulgence.rdias.ac.in/user/default.aspx \\ https:/ / dx.doi.org/10.33601/effulgence.rdias/v17/i1/2019/66-77
}

\author{
Dr. Som Nath Paul ${ }^{1}$ \\ Dr. Rakesh Kumar Yadav ${ }^{2} \triangleleft$
}

\begin{abstract}
This research paper is an explicit effort to understand the role of financial autonomy and personality on investment decision of the individuals of middle class society. In developing countries, middle class society has emerged as most investing community. Investment is not only financial reserve but it is the purposeful act to gain something in future. It is affected by many variables or factors. Financial autonomy is a major factor which influences our living standard, thought process and objectives. It affects our decision making procedure. This financial au tonomy further influenced by our personality to behave differently in a similar situation by two different personalities. A person will take investment decision or not, depends on his/her personality. In this paper, the mediation effect of personality on financial autonomy was also checked to establish the correlation. This research paper is based on two research designs; initially on exploratory research by which the factors were found and then after with the help of descriptive research findings were conducted. The people from the middle class society were taken as test unit. Collected data was verified, tested, investigated and analyzed by different statistical techniques like Exploratory Factor Analysis (EFA), Confirmatory Factor Analysis (CFA) and Structural Equation Modelling (SEM).
\end{abstract}

Keywords: Investment decision, Confirmative factor analysis, Structural Equation Modelling, Mediation Effect.

\section{INTRODUCTION}

$\mathrm{I}$ nvestment decisions are imperative for human beings to support their financial life security. In any economy, individuals take advantage to secure their financial status through investing in yielding securities. Good investment decision can be understood as 'optimum utilization of funds in foresight of future returns'. Investment should not be considered as financial reserve as it is different from one's financial reserve. It is done to create some gathering, for gainful act in upcoming time. In gist, it can be stated that, investment is transformation of cash into resources, which can create future return. Now-a-days plenty of information is available regarding how to invest and which alternative option is more suitable in comparison to others.

1. Assistant Professor, School of Business Management, IFTM University, Moradabad, paulsom1308@gmail.com

2. Professor, School of Business Management, IFTM University, Moradabad, rkymoradabad@rediffmail.com 
Therefore good investment decision making is very crucial. The middle class in emerging economies in Asia, are planning for investment decisions because of availability of modern and complex financial instruments and escalating need for accumulating pension fund or making retirement planning (Grohmann, 2018).

In developing countries, middle class has emerged as most investing community. Banerjee \& Duflo, (2008) classified middle class as people who have an enduring admirably paying occupation. They prefer to have well paid salaried job rather than a petty business. One of the important characteristics of middle class society is that the family size is small and they generally spend on training \& development of their children along with handling medical issues related to family. They also think about their wellbeing and prosperity. This characteristic of middle class society brings at a conclusion that for a middle class society people, a good job is not making handsome money and occupying a well designated position but for them a good job means by which they can afford what they feel good for their family and upbringing of their children. This is against the economic theory which states that good job means generating money through good employment. Therefore it is very much essential for the middle class society people to manage money for their "good job" what they think is good. To manage money for their children's education and for their medical issues and for their retirement life, these middle class people keep on investing which can return them their everyday comforts and which at last prompts higher need of cash. The need to contribute for retirement is twisting up continuously essential as governments coherently move in a contrary course from promising acceptable state benefits.

Saving and investment decision is crucial for a middle class to carry its life serenely and as desired. Use and investment funds are the opposite sides of a similar coin. Investment funds emerge from conceded or relinquished utilization. In any case, the change of reserve funds to speculation requires a solid aim. Savers, who made venture, had an expectation to acquire future returns. Investment is the exchange of money into resources, resources which can produce future return. Investment is a deliberate procedure to convert money into resources and vice-versa.

Investment process satisfies two destinations, first is related with the requirement for changing over reserve funds into investment and second is picking an adjusting approach in choice of securities. Investment decision requires exceptional arranging. Individuals are frequently losing their well deserved cash due to absence of arranging. Investment decision process is affected by many factors (variables). These factors are either internal (inside) or external (outside). External factors are general and common to all, while internal variables differ from individual to individual.

\section{THEORETICAL BACKGROUND FOR STUDY}

As it is discussed earlier that investment decision process is affected by a number of factors (variables). We know external variables are general and common to all, while internal variables differ from individual to individual; therefore it is more important to know the internal variables which can affect the individual investment decisions. The researcher has done a secondary data analysis by reviewing the different studies available, which are discussed as follows:

Li, Z., and Liu, L. (2018) pointed that financial freedom is an essential capacity of a person in choosing about the size, time period, and avenue of his investment. Chen, Ho, \& Liu (2018) emphasized that there is strong evidence that investors' personality influences short-term and long-term trading performance. Aren \& Zengin, (2016) discussed the significant relationship between financial literacy and investment preferences. They explained that simple level of financial literacy as well as advanced level of financial literacy influence the decision of investors. They observed that if 
investors' level of financial literacy is low, they prefer deposit and foreign currency and when financial level of literacy increases, investor tends to create a portfolio or purchase equity. B. R, Neha, (2011) talked about the awareness of investors and stressed that Securities Exchange Board of India (SEBI) and Association of Mutual Funds in India (AMFI) had the obligation to instruct or educate investors which at last helps individual investors. Neha additionally expressed that awareness improvement programs empower the value investors in getting information for different strategies of investment and reducing their risk. Neha valued the activities taken by SEBI and AMFI to create awareness among the investors. Risk perception and level of financial literacy affect individuals' investment preferences. While risk averse investors are tend to having deposit, investors with a high propensity to take risks prefer respectively foreign exchange, equity and portfolio (Aren \& Zengin, 2016). Strauss (2008) concluded that mostly investors in the United States of America take an interest in retirement benefits plans because of their less conception or comprehension of financial report. They plan for long term as they are not aware of day to day trading. Financial knowledge is most critical for an investor for choosing investment plan. Clark and Strauss (2008) focussed on risk. They clarified that investors are either risk taker or risk avoiders. Risk may be characterized by age, sex and circumstance of investors. In a similar setting, Fink and Huston (2003) extended that risk taking capacity of an investor relies upon some more factors, for example, riches, wages, age, married or unmarried and level of literacy and awareness in terms of instructions. Atkinson et Al., (2006) found that individuals who don't contribute or non-savers are for the most part risk-unwilling. Corridor et Al., (2006) individuals who have no interest in investment are risk-loath. It is vital to have the interest of investors. Diacon, S. (2002) built up that perception is the significant explanation for the choice identified with put or not to put resources into value or value situated instrument. Additionally it was included that it is the perception of individual investor which motivates them to averse any risk and it happens because investors percept that their level of knowledge is not upto mark to face such risk while they may have other risk limiting methods. Wurgler, J., and K. Zhuravskaya (2002) in their investigation, found that attitude of investors chooses their investment design in return on value and the coherence of investment in various circumstances chooses whether investment choice will be made or not. Indriani et al. (2018) confined that belief had influenced in constructing perception which confirms that investors behave irrationally. Weinstein (1980) in his investigation uncovered that the belief of an individual characterizes the idea of attitude developed towards some question as positive or negative. In another examination, Buehler and Ross (1994) proposed in one of the paper that the belief of American investor causes him in accomplishing his financial targets inspite of many securities exchange disturbances. Rotter, Julian B. (1954) presented the word locus of control in their research study. The locus of control defines the state of mind of any individual related to the extend they feel that they have the control of their life in their hands. They have the control over the result of occasions in their own lives. The People with an inner locus of control trust that they can compose their very own fate. Thus it is locus of control which decides investor's certainty over their investment choice. Thus on the basis of secondary data analysis the various variables which affect the individual investment decision are financial literacy, attitude, belief, risk, perception, financial freedom, awareness, financial knowledge, interest and locus of control. On the basis of variables found in the secondary data analysis, the following model which is shown in Figure 1, is being constructed for the current study. The model shows that financial autonomy and personality having an influence on investment.

These are the factors (variables) which were used for factor determination and the following hypotheses are framed for testing. 


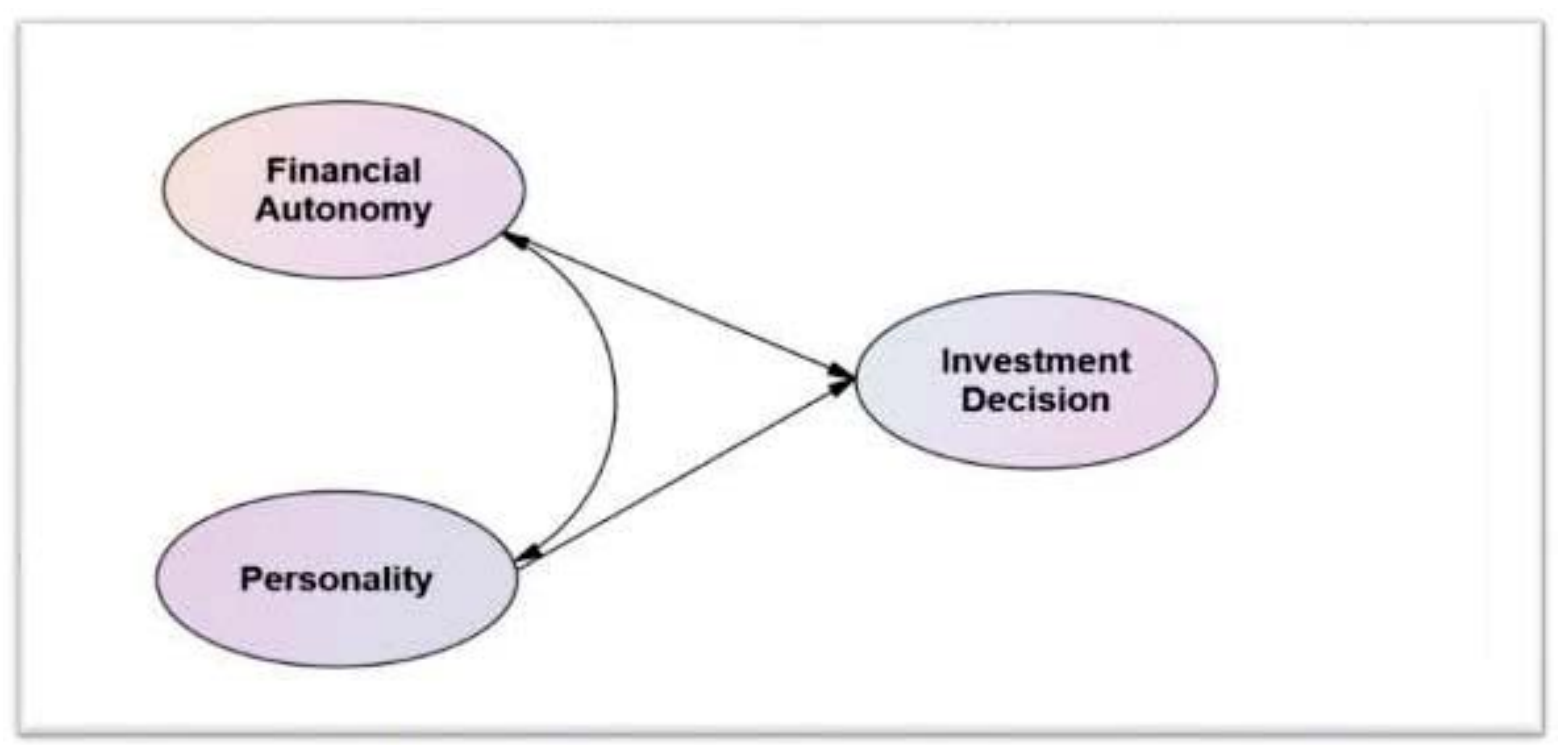

Figure 1: Proposed Model

Source: Based on review of conceptual and empirical literature

\section{Hypotheses}

H1: Investment decision of middle class investor is influenced by financial autonomy and personality.

H2: Financial autonomy has mediating effect on personality.

\section{RESEARCH METHODOLOGY}

The initial research design used for this study was exploratory research design to identify the variables and after that descriptive research design was used to conclude and test the hypothesis. First of all, the secondary data analysis was done to identify the many variables which affect the individual investment decision related to construction of people's investment portfolio and to frame the hypotheses for this study. Secondly, to evaluate those variables and to test the hypotheses, a wellstructured questionnaire was designed. The questionnaire was based on 5 point scale to measure the behavioural aspects related to each of the variables identified.

An individual middle class investor was taken as sample unit of this study; the area chosen for sampling is across North India. The sample units were chosen from the sample frame of 5000 investors' database collected from NDI consultancy. Simple Random Sampling method was used to come across the sample. Questionnaire was prepared and administered in digital mode with the help of Google form. Total six hundred fifty questionnaires were sent to the selected sample units, out of which 544 questionnaires were found properly filled and remaining questionnaires were rejected due to missing information. Data was analysed by different statistical techniques like Exploratory Factor Analysis (EFA), Confirmatory Factor Analysis (CFA) and Structural Equation Modelling (SEM).

\section{DATA ANALYSIS AND INTERPRETATION}

Exploratory factor analysis has been used for analysing the data. Factor analysis was used to understand the relation among the variables and for constructing the model. To test the suitability and adequacy of our sample for the factor analysis, we used the Kaiser-Meyer-Olkin (KMO) test and KMO of our sample is 0.891 which suggests that sample is adequate for factor analysis. Bartlett's test of sphericity test has also verified and suggested the significance of data for factor analysis, as it can be referred from the table (Table : 1 ). 
Table 1 : KMO and Bartlett's Test

\begin{tabular}{|l|l|c|}
\hline \multicolumn{2}{|l|}{ Kaiser-Meyer-Olkin Measure of Sampling Adequacy. } & 0.891 \\
\hline \multicolumn{2}{|c|}{ Bartlett's Test of Sphericity } \\
\hline & Approx. Chi-Square & $\mathbf{3 3 1 2 . 2 0 1}$ \\
\hline & Df & $\mathbf{6 6}$ \\
\hline & Sig. & .000 \\
\hline
\end{tabular}

Source: Researcher's own calculation using SPSS 21

\section{Factor Analysis}

It is also known as factor reduction technique, which helps researcher to combine these similar variables together.

Table 2 : Rotated Component Matrix

\begin{tabular}{|l|c|c|c|}
\hline \multirow{2}{*}{} & \multicolumn{2}{|c|}{ Component } \\
\cline { 2 - 4 } & $1^{*}$ & 2 & \\
\hline Interest & 0.765 & & \\
\hline Locus of control & 0.765 & & \\
\hline Knowledge & 0.713 & & \\
\hline Freedom & 0.683 & & \\
\hline Risk & 0.808 & 0.804 & \\
\hline Awareness & & 0.741 & \\
\hline Perception & & 0.755 & \\
\hline Belief & & 0.707 & \\
\hline Attitude & & & 0.864 \\
\hline InvDeci1 & & & 0.875 \\
\hline InvDeci2 & & & \\
\hline InvDeci3 & & & \\
\hline
\end{tabular}

*Extraction Method: Principal Component Analysis, Varimax Rotation with Kaiser Normalization (5 iterations). (Source: Researcher's own calculation by statistical tool SPSS 21)

All of twelve variables are loaded on different factors. These factors are considered as latent variables. Based on their nature, they are being named as financial autonomy, personality and investment decision, as shown in Table 2. 


\section{Reliability Analysis}

Cronbach's Alpha test was used for testing the reliability of the above latent variables (factor) and questions. The Cronbach's alpha of the above latent variables is shown as below in Table 3:

Table 3 : Croanbach's Alpha Test

\begin{tabular}{|l|l|l|}
\hline Latent Variables & Cronbach's Alpha & Number of Items \\
\hline Financial Autonomy & .849 & 5 \\
\hline Personality & .832 & 4 \\
\hline Investment Decision & .897 & 3 \\
\hline
\end{tabular}

Source: Researcher's own calculation using SPSS 21

\section{Confirmatory Factor Analysis}

Exploratory factor analysis provides only the details regarding different factors loading and their relations. Confirmatory factor analysis helps in quantifying the relations among different latent variables. Researcher has adopted SPSS AMOS version 21 for CFA. The following graph displays the CFA among the latent variables. The standardized estimate result of CFA confirms the correlation among the variables. The correlation is shown in Figure 2.

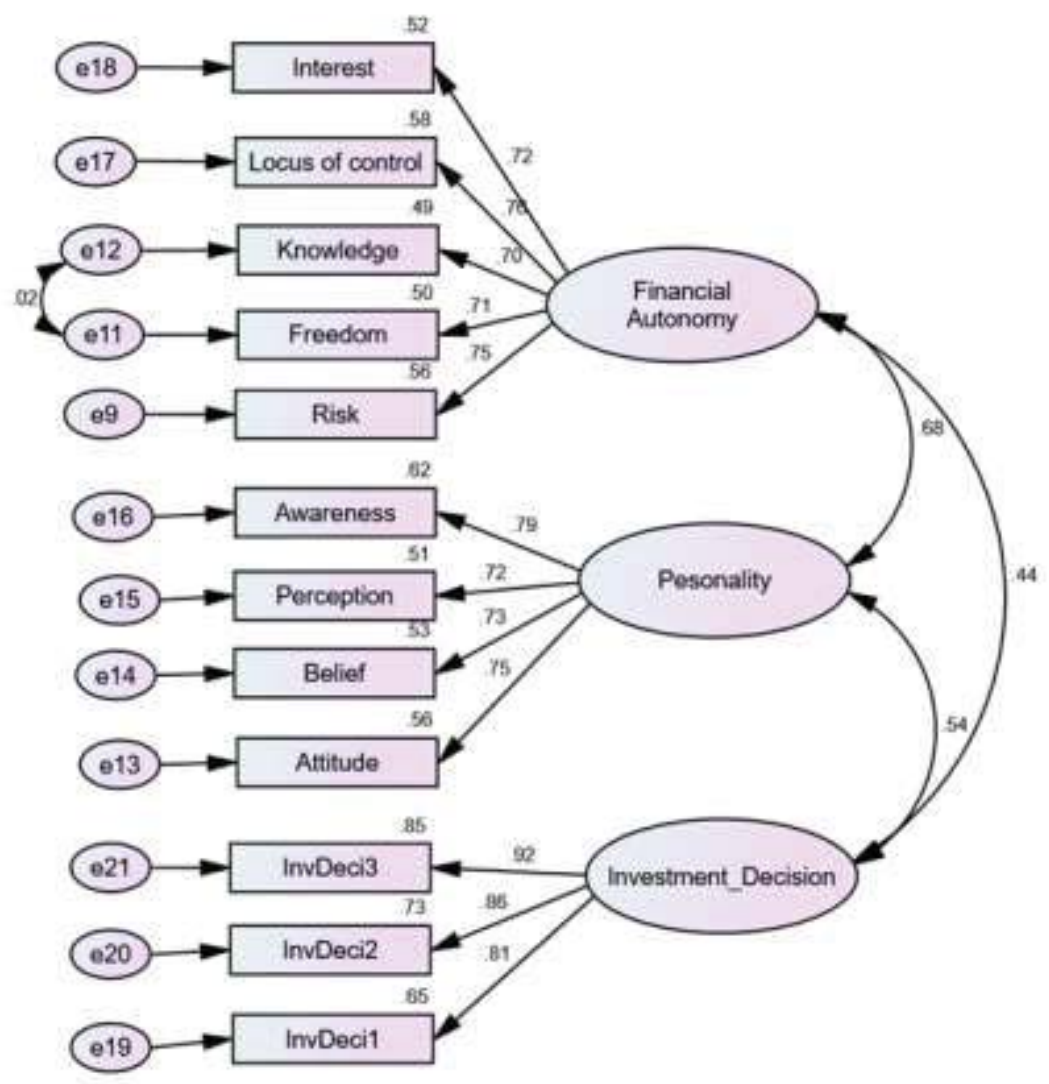

Figure 2: The Role of Financial Autonomy and Personality in Individual Investment Decision Source: Researcher's own calculation using AMOS 21 
The model is being tested with the help of SPSS AMOS version 21, by Gaskin, J. \& Lim, J. (2016), “Model Fit Measures", AMOS Plug-in. The result of model fit is shown in Table 4, as follows:

Table 4 : Model Fit Test result

\begin{tabular}{|l|c|c|c|}
\hline Measure & Estimate & Threshold & Interpretation \\
\hline CMIN & 137.325 & & \\
\hline DF & 50 & & \\
\hline CMIN/DF & 2.746 & Between 1 and 3 & Excellent \\
\hline CFI & 0.973 & $>0.95$ & Excellent \\
\hline SRMR & 0.042 & $<0.08$ & Excellent \\
\hline RMSEA & 0.057 & $<0.06$ & Excellent \\
\hline PClose & 0.156 & $>0.05$ & Excellent \\
\hline
\end{tabular}

Source: Researcher's own calculation using Gaskin, J. \& Lim, J add-on package

As result in the above table are found as excellent that means the above test confirms validity of the constructed model. All latent variables have perfect relation among themselves for further study. In this research paper, the researcher has tried to establish the relation among the different factors which affect the investment decision. It is being established from the above model that there is an excellent relation among the investment decision, financial autonomy and personality. The researcher further established a relation among financial autonomy, personality and investment decision, and also estimates their effect on each other. For which Path analysis method was used which is shown in Figure 3 and it is as follows:

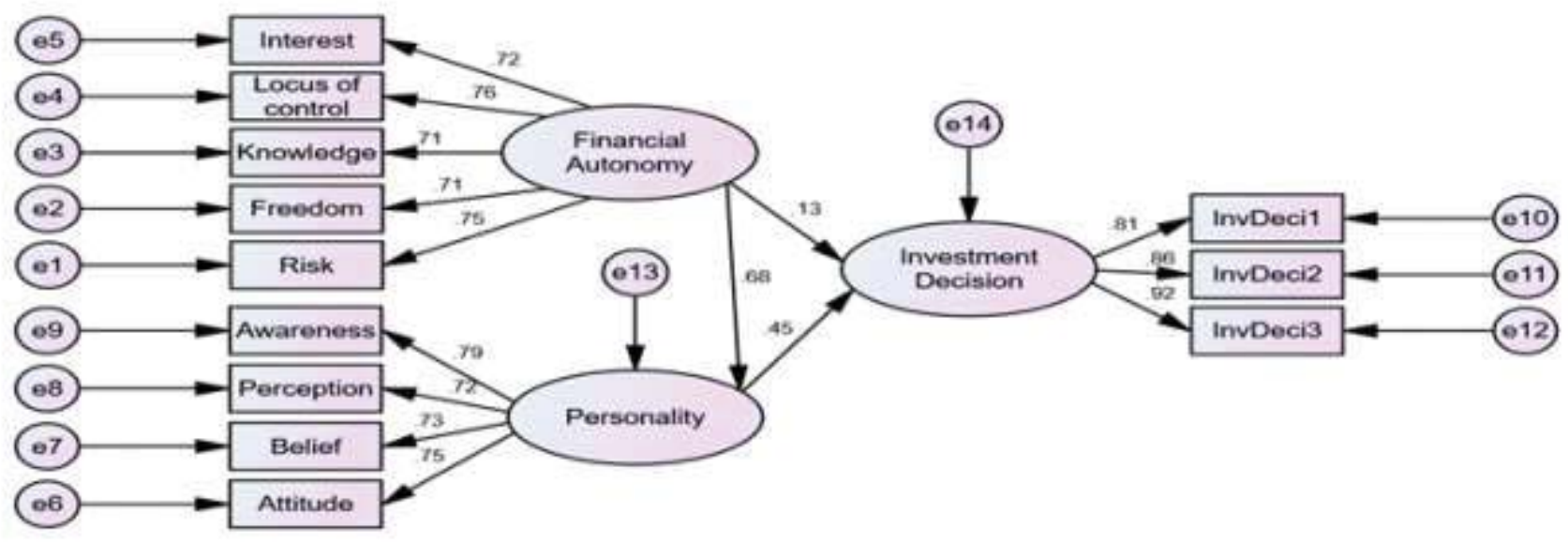

Figure 3 : Path- Analysis

Source: Researcher's own calculation using AMOS 21

It is being inferred from the above graph that, investment decision influenced by financial autonomy and personality. 
Table 5 : Path Analysis Model Fit Test result

\begin{tabular}{|l|c|c|c|}
\hline Measure & Estimate & Threshold & Interpretation \\
\hline CMIN & 137.481 & & \\
\hline DF & 51 & & \\
\hline CMIN/DF & 2.696 & Between 1 and 3 & Excellent \\
\hline CFI & 0.974 & $>0.95$ & Excellent \\
\hline SRMR & 0.042 & $<0.08$ & Excellent \\
\hline RMSEA & 0.056 & $<0.06$ & Excellent \\
\hline PClose & 0.185 & $>0.05$ & Excellent \\
\hline
\end{tabular}

(Source: Researcher's own calculation using SPSS AMOS 21 by Gaskin, J. \& Lim, J)

The model fit confirms the relation being tested in the model. The model confirms that the financial autonomy has a direct effect over the investment decision of individuals, personality further affecting the investment decision. This model fit confirmation is shown in Table 5.

\section{Hypothesis testing}

H1: Investment decision of middle class investor is influenced by financial autonomy and personality.

Table 6 : Coefficients

\begin{tabular}{|l|l|l|l|l|l|l|}
\hline \multicolumn{2}{|c|}{ Model } & \multicolumn{2}{l|}{$\begin{array}{l}\text { Un-standardized } \\
\text { Coefficients }\end{array}$} & $\begin{array}{l}\text { Standardized } \\
\text { Coefficients }\end{array}$ & $\mathrm{t}$ & Sig. \\
\cline { 3 - 7 } & B & Std. Error & Beta & & \\
\hline \multirow{2}{*}{} & (Constant) & .813 & .128 & & 6.344 & .000 \\
\hline & $\begin{array}{l}\text { PeRson } \\
\text { (Personality) }\end{array}$ & .242 & .014 & .604 & 17.665 & .000 \\
\hline
\end{tabular}

Dependent Variable: Inv_DICF (Investment Decision)

Source: Researcher's own calculation using SPSS 21

Table 7 : Coefficients

\begin{tabular}{|l|l|l|l|l|l|l|}
\hline \multicolumn{2}{|c|}{ Model } & \multicolumn{2}{l|}{$\begin{array}{l}\text { Un-standardized } \\
\text { Coefficients }\end{array}$} & $\begin{array}{l}\text { Standardized } \\
\text { Coefficients }\end{array}$ & $\mathrm{t}$ & Sig. \\
\cline { 3 - 7 } & $\mathrm{B}$ & Std. Error & Beta & & \\
\hline \multirow{2}{*}{1} & (Constant) & 1.256 & .140 & & 8.974 & .000 \\
\hline & $\begin{array}{l}\text { Fin_Aut } \\
\text { (Financial } \\
\text { Autonomy })\end{array}$ & .208 & .016 & .484 & 12.888 & .000 \\
\hline
\end{tabular}

Dependent Variable: Inv_DICF (Investment Decision)

Source: Researcher's own calculation by statistical tool SPSS 21 
Result: As it is being inferred from the above Table 06 and 07 that the significance value is 0.00 which states that financial autonomy and personality significantly influences the investment decision of middle class. Thus $\mathrm{H} 1$ is accepted.

\section{H2: Financial autonomy has mediating effect on personality.}

Researcher had used SPSS version 21 to find the mediation effect of personality on financial autonomy and investment decision of middle class investors. Andrew F. Hayes has developed a process function to establish the mediation effect among the unobserved variables. The result of mediation test is shown in the annexure 01 as process output.

Result: It can inferred from the process test results given in annexure 01 that investment decision (dependent variable) having a significant effect of financial autonomy as beta value ( $p$ ) received less than .001 and there is no zero occurred between the Lower Limit of Confidence Index (LLCI) i.e. 0.7520 and Upper limit of confidence index (ULCI) i.e. 0.8706. Process procedure also depicted the significant impact of personality over the investment decision. The model fit measure test confirmed that personality has a full mediating effect on financial autonomy of middle class investor, as showed in the process test results given in annexure 01, the beta value (p) i.e. 0.2190 of financial autonomy and there is zero occurred between the Lower Limit of Confidence Index (LLCI) i.e. -0.0165 and Upper limit of confidence index (ULCI) i.e. 0.0717 which explains that the effect of financial autonomy becomes insignificance in the presence of society. Thus $\mathrm{H} 2$ is accepted.

\section{INTERPRETATION \& CONCLUSION}

As it has been seen in the path analysis that the personality is most influenced by awareness $(p=0.79)$ of the investor, then by attitude $(p=0.75)$ of the investor, belief $(p=0.73)$ and perception $(p=0.72)$ of the investor has the least influence on personality of the investor. On the other hand, the financial autonomy is most influenced by locus of control $(p=0.76)$ then by risk taking capacity of the investor $(p=0.75)$, interest of the investor $(p=0.72)$, financial freedom of the investor $(p=0.71)$ and the knowledge about the instrument $(p=0.70)$ has the least influence on financial autonomy of the investor. Thus it can be inferred from the path analysis that all variables were considered as important and significant factors that influences investment decision.

The current study ends with outcomes which approve that investment decision process of middle class investors influenced by his financial autonomy and personality. It reflects that personality of individual plays an important role in determining his behaviour to choose Investment Avenue, our study approves the work of Zandri et al (2018), which have mentioned that personality is influential factor for determining investment decision. Financial freedom, financial knowledge, freedom, locus of control and his interest in financial instrument determine his investment plan. But personality of individual has a mediating effect on financial autonomy factor of middle class investors.

So it is being concluded from the study that "middle class investor's financial position influence his investment decision; whereas personality mediate this effect". It means two persons of same middle class category having the same financial position may react differently related to investment decision due to their different personalities. Thus it is infact the personality which creates the difference and forces a person to take investment decision.

\section{LIMITATIONS \& FUTURE SCOPE OF THE STUDY}

Investors' own data is harder to characterize, which makes it hard to complete a nitty gritty quantitative analysis. Hence, this research adopted a questionnaire analysis plan. The investors' private data was tough to collect and true data was hard to acquire because many times the respondents did not know exact factor influencing their investment 
decision. The very theoretical nature of investing implied that structuring the questionnaire took quite a long time. During this study, the trouble of gathering and acquiring significant, critical, private data was one of the limitations of this examination. The responses were found to be different in different frame of time. Sometimes the respondents became furious and irritated due to length of the questionnaire. This reduces the validity of the questionnaire.

Future, studies can be carried by diversifying the sample units by extending it to other categories of investors such as 'high net worth income group', 'financial advisors', etc. The same study can be carried out separately for different financial products, such as insurance, mutual funds and equity etc.

\section{REFERENCES}

1) Aren, S., \& Zengin, A. N. (2016). Influence of Financial Literacy and Risk Perception on Choice of Investment. Procedia - Social and Behavioral Sciences, 235(October), 656-663. https://doi.org/10.1016/j.sbspro.2016.11.047

2) Analysis, The Guilford Press, New Work, London, P. 85-122,

3) Banerjee, A. V, \& Duflo, E. (2008). What is Middle Class about the Middle Classes around the World?, 22(2), 3-28.

4) Etty Indriani and Cahyani Tunggal Sari (2018). Behavioral finance: the analysis of investor behavior based on belief and feeling and the investor rationality towards LQ 45 stocks. Investment Management and Financial Innovations, 15(1), 292-298. doi: 10.21511/imfi.15(1).2018.24

5) Grohmann, A. (2018). Pacific-Basin Finance Journal Financial literacy and fi nancial behavior : Evidence from the emerging Asian middle class. Pacific-Basin Finance Journal, 48(January), 129-143. https://doi.org/10.1016/ j.pacfin.2018.01.007

6) Hayes, F. Andrew (2013), Introduction to
Mediation, Moderation, and Conditional Process.

7) Hall, S., Pettigrew, N. and Harvey, P. (2006), Public attitudes to personal accounts: report of a qualitative study (DWP Research Report 370).

8) Li, Z., \& Liu, L. (2018), Financial globalization, domestic financial freedom and risk sharing across countries. Journal of International Financial Markets, Institutions and Money, 55, 151-169.

9) Rotter, J.B., Chance, J.E. and Phares, E.J. (1972); Applications of a Social Learning Theory of Personality.

10) Rotter, J.B. and Hochreich, D.J. (1975): Personality.

11) Rotter, J.B. (1954); Social Learning and Clinical Psychology.

12) Sethi-Iyengar, S., Huberman, G. and Jiang, W. (2004) How much choice is too much? Contributions to $401(\mathrm{k})$ retirement plans, In Pension design and structure: New lessons from behavioral finance (Eds, Mitchell, O. and Utkus, S.) Oxford University Press, Oxford.

13) Sethi-Iyengar, S. and Kamenica, E. (2006) Choice overload and simplicity seeking, University of Columbia Graduate School of Business Working Paper.

14) Sethi-Iyengar, S., Huberman, G. and Jiang, W. (2004) How much choice is too much? Contributions to $401(\mathrm{k})$ retirement plans, In Pension design and structure: New lessons from behavioral finance (Eds, Mitchell, O. and Utkus, S.) Oxford University Press, Oxford.

15) Sethi-Iyengar, S. and Kamenica, E. (2006) Choice overload and simplicity seeking, University of Columbia Graduate School of Business Working Paper.

16) Summers, B., Ironfield-Smith, C., Duxbury, D., Hudson, R. and Keasey, K. (2005) Informed choice: consumer preferences for information on pensions, Journal of Financial Regulation and Compliance, 13.

17) Samuelson, P., and Zeckhauser, R. (1988). Status quo bias in decision making, Journal of Risk and Uncertainty 1: 7-59. 
18) Shefrin, H. (2000). Beyond greed and fear: understanding behavioral finance and the psychology of investing (Harvard Business School Press, Boston).

19) Shiller, R. (2005). Lifecycle Portfolios as Government Policy. The Economists' Voice, 2(1), Article 14.

20) Ting-Hsuan Chen, Ruey-Jenn Ho, Yi-Wei Liu, Investigating the Predictive Power of Investor Personality in Forecasting Investment Performance using machine learning models, Computers in Human Behavior (2018), doi: 10.1016/j.chb.2018.09.027
21) Wurgle, J \& Zhuravskayar. E (2002). The Journal of Business, vol. 75, issue 4, 583-608

22) Weinstein, N. D. (1980). Unrealistic optimism about future life events. Journal of Personality and Social Psychology, 39(5), 806-820.

23) Zandri Dickason, Sune Ferreira, David McMillan. (2018) Establishing a link between risk tolerance, investor personality and behavioural finance in South Africa. Cogent Economics \& Finance 6:1, pages 1-13. 


\section{Annexure 1 : Process Output}

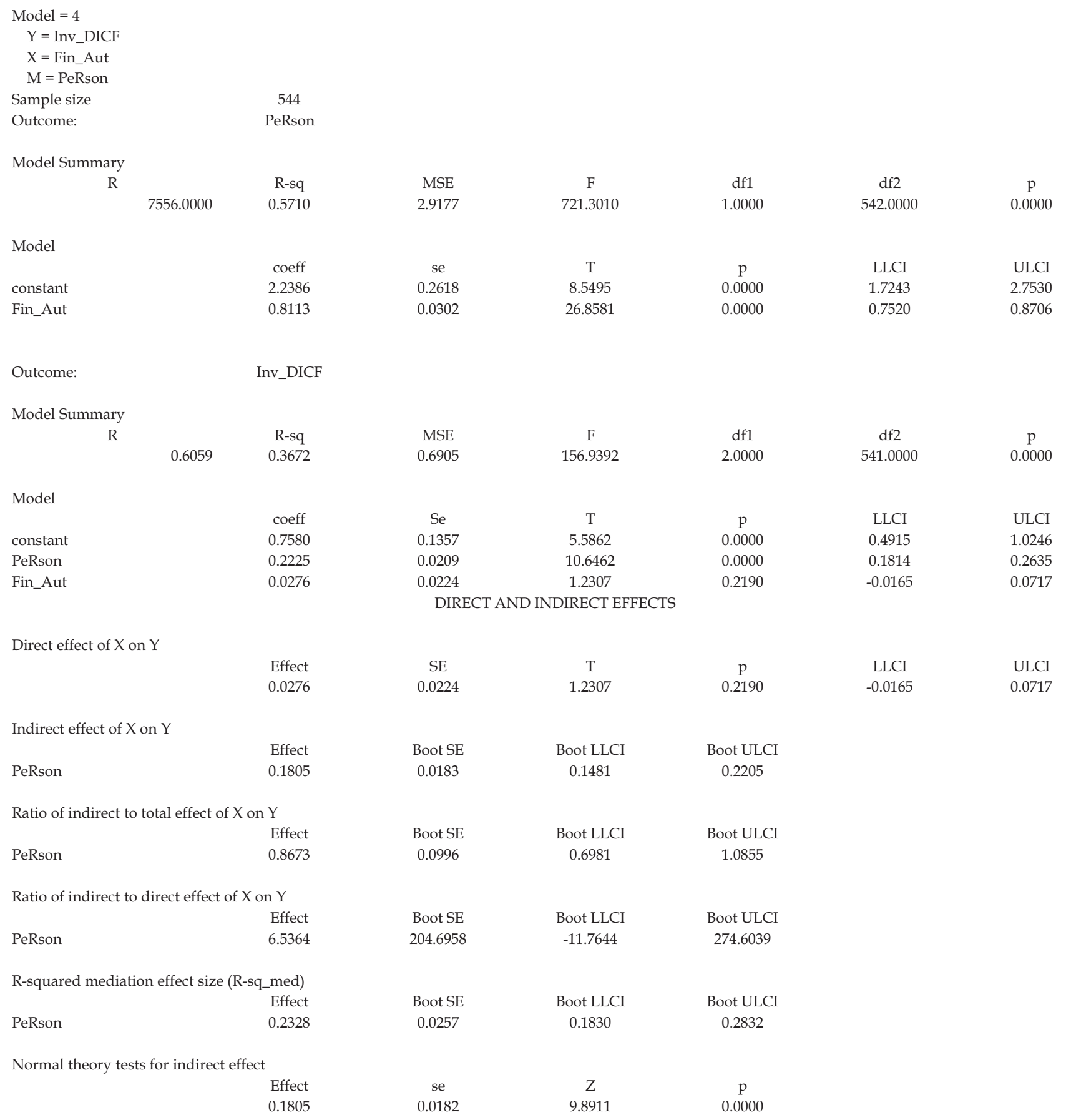

Source: Researcher's own calculation by statistical tool SPSS 21 Process Tool by Andrew F. Hayes 